\title{
PELAKSANAAN ASAS PELAYANAN PUBLIK PADA PUSKESMAS SIMPANG BARU KOTA PEKANBARU
}

\author{
Harapan Tua F S, Syofian \\ Universitas Riau \\ e-mail: harapantua@ lecturer.unri.ac.id
}

\begin{abstract}
Public services are the result of organizing organizations. Starting from all forms of activities in the arrangement, guidance, guidance, providers of facilities, services and others carried out by organizations engaged in the public sector. One public institution that organizes public services is the puskesmas while still paying attention to the principles of public service created by the institution in providing services to the community. The purpose of this study was to study the principles of service at the Simpang Baru Health Center, Simpang Baru Village, Tampan District, Pekanbaru City. The researcher uses a qualitative method that describes the implementation of the principles of public service by studying and studying the theory as a guide. Research informants are Puskesmas employees and the community as patients at Puskesmas with data collection techniques namely observation and interviews.
\end{abstract}

Keywords: Services, principles of service, patients, employees

Abstrak
Pelayanan publik merupakan output dari organisasi penyelenggara pelayanan kepada masyarakat mulai dari segala bentuk kegiatan dalam rangka pengaturan, pembinaan, bimbingan, penyedia fasilitas, jasa dan lainnya yang dilaksanakan oleh organisasi yang bergerak dibidang urusan publik. Salah satu Lembaga publik yang menyelenggarakan pelayanan publik adalah puskesmas dengan tetap memperhatikan asas-asas pelayanan publik yang dijadikan landasan dalam memberikan pelayanan kepada masyarakat. Tujuan penelitian ini untuk mengetahui asas-asas pelayanan pada Puskesmas Simpang Baru Kelurahan Simpang Baru Kecamatan Tampan Kota Pekanbaru. Peneliti mengunakan metode kualitatif yang bersifat mendeskripsikan tentang pelaksanaan asas-asas pelayanan publik dengan telaah dan kajian berdasarkan teori sebagai pedoman. Informan penelitian adalah pegawai Puskesmas dan masyarakat sebagai pasien di Puskesmas dengan Teknik pengumpulan data yaitu observasi dan wawancara.

Kata Kunci : Pelayanan, asas-asas pelayanan, pasien, pegawai

\section{PENDAHULUAN}

Pelayanan publik menjadi sesuatu berharga pada era organisasi modern karena merupakan proses dimana ada orang yang dilayani, melayani, dan jenis pelayanan yang berikan. Peran penting pelayanan publik ada pada setiap jenjang instansi publik agar dapat mendekatkan pelayanan publik kepada masyarakat. Asrida (2013) pelayanan publik pada Puskesmas merupakan bentuk kepedulian dan kewajiban pemerintah kota Pekanbaru terhadap masyarakatnya. Hal ini menunjukkan pentingnya publik sebagai bagian dari penyelengaraan negara. Sebagai suatu kewajiban instansi pemerintah pelayanan publik dituntut memberikan pelayanan berkualitas bagi masyarakat yang merupakan sebagai suatu 
kewajiban yang harus dipenuhi oleh pemerintah dalam rangka memberikan kepuasan yang optimal bagi masyarakat pengguna layanan.

Pelaksanaan pelayanan publik oleh instasi pemerintah terutama bidang kesehatan pada Puskesmas harus menerpakan prinsip-prinsip tata kelola pelayanan yang baik dengan komitmen yang kuat dari instansi penyelenggara. Bandiyono (2018) baiknya kinerja instansi pelayanan piblik tergantung kepada kerjasama tim, hubugan baik vertical dan horizontal organisasi, pembagian kerja secara professional, partisipasi masyarakat, budaya organisasi baik dan dukungan pimpinan oragnisasi. Berkaitan dengan itu dalam Peraturan pemerintah tentang pelaksanaan Undang-Undang Nomor 25 Tahun 2009 tentang pelayanan publik bahwa kegiatan atau rangkaian kegiatan dalam rangka pemenuhan kebutuhan pelayanan sesuai dengan Peraturan Perundangan bagi setiap warga negara dan penduduk atas barang jasa dan atau pelayanan administratif yang disediakan oleh penyelenggara pelayanan publik harus memenuhi asas pelayanan publik. Adapun asas pelayanan publik harus memenuhi asa kepentingan umum, kepastian hukum, kesamaan hak, keseimbangan hak dan kewajiban, professional, partisipatif, tidak diskriminatif keterbukaan, akuntabilitas, fasilitas, ketepatan waktu, mudah dan terjangkau.

Asas dan tujuan pelayanan publik dipakai untuk pedoman dalam penyelengaraan pelayanan publik oleh instansi pemerintah dan dapat dijadikan sebagi indikator terhadap kualitas pelayanan yang telah diberikan oleh penyelenggara pelayanan publik untuk memenuhi tuntutan pelayanan dari publik. Hamzah (2016) mengutip pendapat Zeithaml, et.al dalam penyelenggaraan pelayanan publik harus memenuhi dimensi pelayanan publik sebagai berikut:

1. Tangibles (kualitas pelayanan yang berupa sarana fisik perkantoran, komputerisasi administrasi, ruang tunggu, tempat informasi, dan sebagainya);

2. Reliability (kemampuan dan keandalan untuk menyediakan pelayanan yang terpercaya);

3. Responsiveness (kesanggupan untuk membantu dan menyediakan pelayanan secara cepat dan tepat, serta tanggap terhadap keinginan konsumen);

4. Assurance (kemampuan dan keramahan, serta sopan santun aparat dalam meyakinkan kepercayaan konsumen);

5. Emphaty (sikap tegas tetapi penuh perhatian dari aparat terhadap konsumen).

Berkaitan dengan dimensi pelayanan publik Zeithaml, et.al(1990), menemukan dengan menggambarkan gap-gap dalam pelayanan publik tersebut:

a. Kesenjangan antara harapan publik (expected service) dengan persepsi manajemen (Management Perception of Costumer Expectation).

b. Kesenjangan antara persepsi manajemen (Management Perception of Costumer Expectation) dengan spesifikasi kualitas pelayanan (Service Quality Specification).

c. Kesenjangan antara spesifikasi kualitas pelayanan (Service QualitySpesification), dengan penyampaian pelayanan (Service Delivery).

d. Kesenjangan antara komunikasi eksternal kepada publik (External Communication to Costumers) dengan proses penyampaian pelayanan (Service Delivery).

e. Kesenjangan antara pelayanan yang diharapkan publik (Expected Service) dengan pelayanan yang dirasakan oleh publik (Perceived Service).

Kebutuhan Dasar dalam pelayanan publik yang harus dipenuhi oleh penyelengara pelayanan publik salah satu yang menjadi topik dan isu dan menjadi masalah adalah Sektor kesehatan yang menerapkan konsep pelayanan yang berwawasan masyarakat. Undang-Undang Nomor 36 Tahun 2009 tentang Kesehatan menyatakan bahwa "Setiap orang berhak atas taraf hidup yang memadai bagi kesehatan termasuk perawatan kesehatan dan berhak atas jaminan di saat menderita sakit". Setiap orang mempunyai hak yang sama dalam memperoleh derajat kesehatan yang optimal. 
Uniknya sektor kesehatan merupakan kinerjanya tidak dapat diukur secara ekonomis saja, karena syarat dengan aspek sosial kemanusiaan. Salah satu Instansi yang menyelenggarakan pada level terendah adalah Puskesmas yang melakukan pelayanan jasa juga adalah organisasi pelayanan publik yang berada pada tingkat daerah/kecamatan yang berfungsi menyelenggarakan pelayanan kesehatan. Secara teoritik menurut Lipsky (David, 2010), birokrasi Puskesmas dikategorikan sebagai street level bureaucracy, yaitu birokrasi yang menjalankan tugas berhadap-hadapan dengan masyarakat dimana karena peran dan kedudukannya itu birokrasi menjadi representase pemerintah dimata publik, operasi birokrasi pada level terbawah menyangkut urusan kebutuhan dasar masyarakat.

Perkembangan Puskesmas untuk menata lembaganya searah dengan paradigma pembangunan kesehatan yaitu "paradigma sehat" dengan tujuan untuk peningkatan mutu, pemerataan dan efisiensi mendorong Puskesmas untuk senantiasa berupaya melakukan reformasi. Salah satu cara pencapaian reformasi birokrasi pada instansi pelayanan kesehatan adalah penerapan standar ISO-9001. Menurut Van den Heuvel (2005), standar ISO-9001 merupakan standar internasional tentang sistem manajemen mutu dimana sebuah organisasi dapat mewakili sebuah konsensus internasional tentang praktek-praktek manajemen yang baik dengan tujuan untuk memastikan bahwa organisai dapat secara berkesinambungan menghasilkan produk atau jasa yang memenuhi persyaratan perundangan, meningkatkan kepuasan pelanggan dan mencapai perbaikan berkesinambungan dalam mencapai tujuan-tujuan tersebut.

Penyelenggaraan pelayanan kesehatan berdasarkan Undang-Undang Nomor 36 Tahun 2009 tentang Kesehatan disebutkan bahwa pelayanan kesehatan terdiri atas pelayanan kesehatan perseorangan dan pelayanan kesehatan masyarakat. Pelayanan kesehatan sebagaimana dimaksud meliputi kegiatan dengan pendekatan promotif, preventif, kuratif dan rehabilitatif. Apapun bentuk layanan publik tentu yang diharapkan itu adalah Kepuasan masyarakat karena merupakan faktor yang sangat penting dan menentukan keberhasilan suatu layanan publik, karena masyarakat adalah konsumen dari produk yang dihasilkannya, tanpa publik berarti lembaga tersebut tidak ada. Kepuasan masyarakat menurut Mowen (1995:39) adalah seluruh perilaku masyarakat terhadap penggunaan barang dan jasa, oleh karena itu pencapaian pemenuhan memenuhi kebutuhan dan keinginan masyarakat sehingga mencapai kepuasan masyarakat dan lebih jauh lagi ke depannya dapat dicapai kesetiaan masyarakat. Sebab, bila tidak dapat memenuhi kebutuhan dan kepuasan masyarakat sehingga menyebabkan ketidakpuasan masyarakat mengakibatkan kesetiaan masyarakat akan hilang dan beralih ke layanan swasta.

Pendapat Kotler (1997:15) menyebutkan bahwa masyarakat akan puas apabila harapannya dilebihkan. Harapan yang dimaksud ialah sesuai dengan persepsi awal akan kualitas produk tersebut, dan persepsi tersebutdisesuaikan dengan pengalaman masa lalu. Konsep dan teori mengenai kepuasan publik telah berkembang pesat dan telah mampu diklasifikasikan atas beberapa pendekatan. Salah satu pendekatan yang paling populer yang berhubungan dengan kepuasan publik adalah teori The Expectancy Disconfirmation Model dari Zeithaml et.al(1990:167). Teori ini menekankan bahwa kepuasan atau ketidakpuasan ditentukan oleh suatu proses evaluasi publik, dimana persepsi tersebut mengenai hasil suatu jasa atau jasa dibandingkan dengan standar yang diharapkan. Proses inilah yang disebut dengan proses diskonfirmasi.

Berkaitan dengan perkembangan teori dan tuntutan terhadap penyelenggara pelayanan publik ada fenomena unik dalam pelaksanaan pelayanan publik pada Puskesmas Simpang Baru Kecamatan Tampan Kota Pekanbaru, berhasil melaksanakan kegiatan pelayanan kesehatan mulai dari promotif, preventif, kuratif dan rehabilitative, padahal sebelumnya Puskesmas ini menjadi bahan pembicaraan dalam memberikan pelayanan mulai dari dokter yang tidak menetap dan kurangya aktifitas pelayanan dilakukan pada saat jam pelayananan. Berdasarkan fenomena itu maka peneliti tertarik untuk melihat palaksanaan asas pelayanan publik yang dilakukan oleh Puskesmas Simpang Baru Kelurahan Simpang Baru Kecamatan Tampan Kota Pekanbaru. 


\section{METODE}

Penelitian ini dilakukan di Puskesamas Simpang Baru Kecamatan Tampan Pekanbaru, dengan objek penelitian pada pelaksanaan asas pelayanan kesehatan berpijak pada lima dimensi kualitas pelayanan. Permasalahan pelayanan kesehatan belum dapat terpenuhi sebagaimana yang diharapkan dalam pelayanan kesehatan yang diberikan oleh pihak Puskesmas kepada masyarakat/pasien baik dalam hal promotif, preventif, kuratif dan rehabilitative. Keluhan-keluhan masyarakat tentang pelayanan kesehatan terutama Puskesmas Simpang Baru perlu mendapat perhatian yang serius. Sampai saat ini penelitian yang cermat dan handal tentang pelayanan kesehatan pada Puskesmas Simpang Baru. Di dalam penelitian ini peneliti menggunakan Metode Penelitian Kualitatif. Peneliti menggunakan metode kualitatif karena sesuai dengan judul Pelaksanaan Asas Pelayanan Publik Pada Puskesmas Simpang Baru Kota Pekanbaru. Peneliti lebih tepat menggunakan metode kualitatif karena penelitian ini tidak menggunakan angka. Menurut Moleong (1998:6), penelitian kualitatif adalah penelitian yang bermaksud untuk memahami fenomena tentang apa yang dialami oleh subyek penelitian, misalnya perilaku, persepsi, motivasi, tindakan dan lain-lain, secara holistik dan dengan suatu konteks khusus yang alamiah dan dengan memanfaatkan berbagai metode alamiah. Selain itu kualitatif lebih dapat menyentuh secara mendalam aspek behavioral skala kecil, lebih dapat mengungkap rincian kompleks tentang fenomena lapangan. Maka diharapkan lahirnya preposisi hipotetik baru melalui intrepretasi interaksi antara atribut dan propertis yang selanjutnya dapat digunakan untuk membangun kategori dan memberikan eksplanasi terhadap fenomena yang diteliti. Harapan tersebut dapat terpenuhi melalui pendekatan kualitatif. Tujuannya adalah mengumpulkan data sebagaimana adanya (das sein) menurut persepsi dan pandangan dari beberapa komponen yang ada dalam Pelaksanaan Asas Pelayanan Publik Pada Puskesmas Simpang Baru Kota Pekanbaru, baik pasien, keluarga pasien, kepala bidang perawatan atau penanggung jawab. Hal ini tentunya didukung dengan referensi teori lima dimensi yang dibangun dalam kerangka pemikiran. Aktivitas penelitian yang dilakukan melalui serangkaian kegiatan mengumpulkan, menggambarkan dan menafsirkan data tentang situasi yang dialami, kegiatan, hubungan tertentu, pandangan atau sikap yang ditunjukkan atau tentang kecenderungan yang tampak dalam proses yang sedang berlangsung. Melalui desain ini dapat diperoleh gambaran fenomena, fakta, sifat serta hubungan fenomenal tentang implementasi kebijakan sehingga dapat dilakukan kategorisasi dan jawaban atas perumusan hipotesis sebagai temuan penelitian. Instrumen dalam penelitian kualitatif haruslah dipahami bahwa dimana seorang peneliti adalah juga instrumen penelitian, sebab keabsahan data dan informasi yang dikumpulkannya sangat bergantung pada keahlian, kecakapan dan pengalaman peneliti serta pemahaman tentang karakteristik lapangan dimana penelitian dilakukan.

Ada 2 (dua) jenis data yang digunakan dalam penelitian ini, yakni sumber data utama atau primer dan sumber data tambahan atau sekunder. Prime source of data (sumber data utama) dalam penelitian kualitatif ini seluruh kegiatan di lapangan berupa pernyataan (statement) seperti media massa, statement perorangan, statement kelompok dan tindakan dari semua informan atau pihak yang diteliti, dengan cara kombinasi melihat dan mengamati, mendengar dan menyimak, kemudian menanyakan. Sumber data primer yang dimaksud adalah data dari semua pihak dimana diharapkan data yang akurat, lengkap dan mendalam. Dimulai dari informan yang secara representatif dapat mewakili seluruh obyek penelitian yang dimaksud. Selain data primer juga dibutuhkan data sekunder berupa dokumen tertulis bersumber dari artikel, studi literatur, program kerja, dokumen dan foto, dokumen penanganan pelayanan. Kemudian kebijakan publik berupa peraturan, publikasi pihak rumah sakit tentang pelayanan kesehatan pada media massa dan sebagainya. Informan didasarkan pada kriteria sesuai dengan tujuan penelitian. Informan ditetapkan berdasarkan pertimbangan bahwa mereka dianggap dapat memberikan data dan informasi mengenai diwawancarai adalah representasi dari pelayanan dan penerima layanan publik dari Puskesmas Simpang Baru Kelurahan Simpang Baru Kecamatan Tampan Kota Pekanbaru. Selain itu 
peneliti sebagai instrumen utama dalam pelaksanaan penelitian ini, juga menggunakan instrumen penunjang lain seperti dokumentasi, wawancara mendalam dan observasi dalam pengumpulan data. Sedangkan analisis data adalah analisa deskriptif kualitatif. Data dikumpulkan terlebih dahulu oleh peneliti sebelum diinterpretasikan. Artinya data diproses terlebih dahulu melalui prosedur atau pentahapan yang sistematis, melalui tahapan umum prosedur pengolahan data kualitatif.

\section{HASIL DAN PEMBAHASAN}

Kegiatan pelayanan merupakan suatu usaha untuk membantu menyiapkan atau mengurusi apa yang diperlukan masyarakat yang ditujukan dalam upaya meningkatan kesejahteraan masyarakat. Pelayanan pada sector kesehatan merupakan salah satu bentuk kegiatan nyata untuk meningkatkan kesejahteraan masyarakat. Puskesmas Simpang Baru sebagai lembaga kesehatan milik pemerintah untuk melaksanakan pelayanannya berpedoman pada standar pelayanan menurut Keputusan Menteri Pendayagunaan Aparatur Negara No.63/KEP/M.PAN/7/2003 dan Undang-Undang Nomor 25 Tahun 2009 tentang pelayanan publik kepada prosedur pelayanan, waktu penyelesaian, biaya pelayanan, produk pelayanan, sarana dan prasarana, serta kompetensi petugas pemberi pelayanan. Mengacu pada keputusan Menteri Pendayaguanaan Aparatur Negara tersebut, berikut data hasil penelitian masing- masing standar pelayanan.

\section{Prosedur Pelayanan}

Prosedur pelayanan merupakan tahapan kegiatan yang dilakukan dalam proses penyelesaian pelayanan yang dilakukan bagi pemberi dan penerima pelayanan termasuk pengaduan. Penerapan prosedur pelayanan tidak berbelit-belit, mudah dipahami dan dilaksanakan sesuai syarat administratif atau peraturan dari instansi/lembaga. Berdasarkan hasil dokumentasi dan wawancara, prosedur pelayanan di Puskesmas Simpang Baru dilaksanakan sesuai dengan alur pelayanan kepada pasien di depan pendaftaran pasien, jadi pasien yang datang bisa langsung membaca dan mengetahui alur pelayanan di Puskesmas Simpang Baru.

Alur pelayanan di Puskesmas Simpang Baru dapat dilihat dalam gambar 1.Secara umum alur pelayanan di Puskesmas Simpang Baru dimulai dari pasien datang kemudian ke bagian pendaftaran untuk mengambil nomor antrian. Pasien yang telah mendapatkan nomor antrian menunggu dipanggil sesuai nomor antrian yang didapatkan, kemudian setelah dipanggil, pasien masuk ke ruangan poli/bagian pelayanan yang dituju guna melakukan pemeriksaan. Setelah pasien selesai diperiksa kemudian dokter memberikan diagnosa kepada pasien untuk selanjutnya mendapatkan rujukan atau hanya mendapat obat jalan. Pasien kemudian ke bagian kasir untuk melakukan pembayaran. Pasien yang telah membayar biaya pelayanan dan obat, dapat mengambil obat di bagian obat dan pasien boleh pulang.

Prosedur pelayanan di Puskesmas Simpang Baru juga terbagi dalam setiap bagian yaitu, prosedur pelayanan bagian pendaftaran, proseur pelayanan BP Umum, prosedur pelayanan KIA/KB, prosedur pelayanan caten (calon penganten), prosedur pelayanan konsultasi psikologi. Prosedur pendaftaran di Puskesmas Simpang Baru yaitu Pasien datang mengambil nomor antrian dan dipersilahkan duduk, setelah itu mengisi form pendaftaran dan menunjukkan kartu identitas serta kartu jaminan kesehatan. Pasien dibagi menjadi tiga bagian yaitu pasien baru, pasien lama, dan pasien lebih dari satu poli. Petugas membuatkan kartu pendaftaran untuk pasien baru, kemudian pasien mendapatkan kartu tunggu poli. Petugas langsung memberikan kartu tunggu poli untuk pasien lama, dan pasien lebih dari satu poli, petugas memberikan nomor antrian poli lebih dari satu dan memberikan nomor rekam medis sesuai poli yang dituju. 


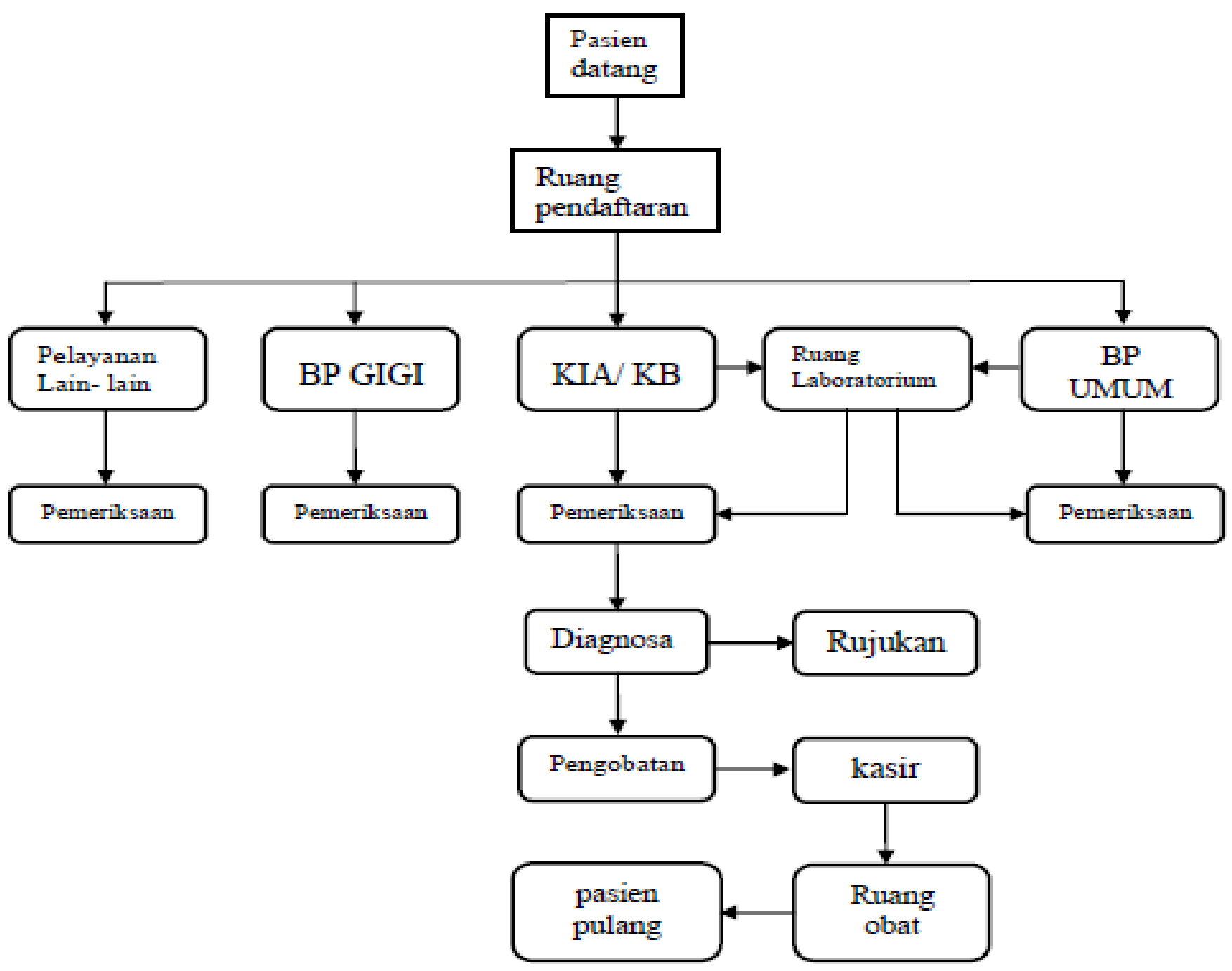

Gambar.1. Prosedur Palayanan Puskesmas Simpang Baru

Petugas kemudian mempersilahkan pasien duduk dan menunggu di depan poli yang dituju. Prosedur pendaftaran di Puskesmas Simpang Baru dapat dilihat pada gambar 3 sebagai berikut: 


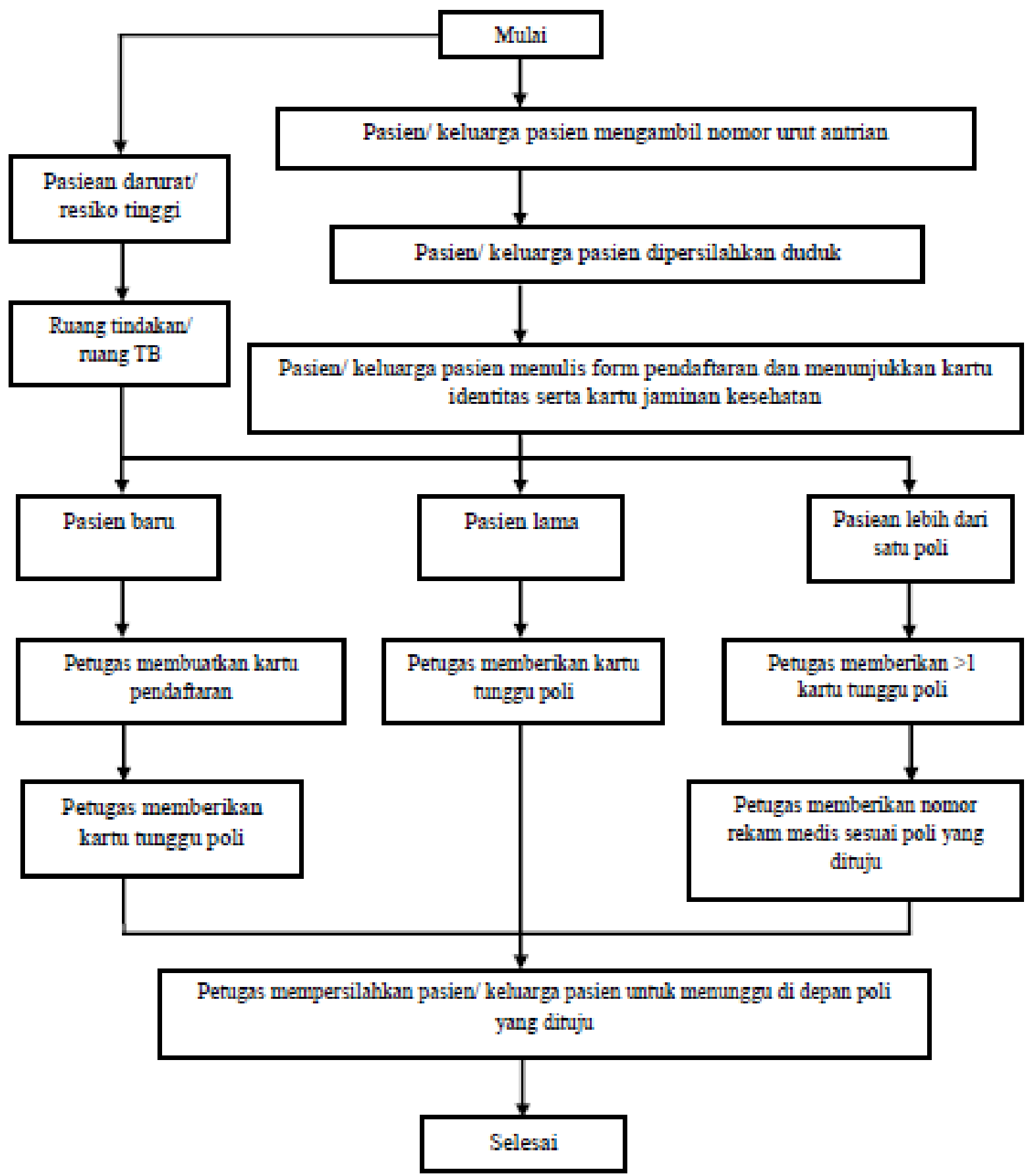

Gambar.2. Prosedur Pendaftaran Pasien Puskesmas Simpang Baru

Puskesmas sebagai unit pelayanan kesehatan tingkat pertama yang mendukung terwujudnya derajat kesehatan yang optimal harus melaksanakan pelayanannya dengan semaksimal mungkin. Sub indikator pelaksanaan pelayanan di Puskesmas Simpang Baru meliputi : 


\section{Prosedur Pelayanan di Puskesmas Simpang Baru}

Prosedur pelayanan adalah tahapan yang harus dilalui dalam proses penyelesaian pelayanan. Berdasarkan Keputusan Menpan No. 63/KEP/M.PAN/7/2003, Tentang Pedoman Umum Penyelenggaraan Pelayanan Publik, dicantumkan bahwa prosedur pelayanan publik sederhana, tidak berbelit-belit, mudah dipahami dan mudah dilaksanakan. Prosedur merupakan tahapan kegiatan yang dilakukan dalam proses pelayanan. Sistem dan prosedur tersebut termasuk dalam standar pelayanan yang diterapkan oleh Puskesmas Simpang Baru dalam pelaksanaan pelayanannya agar masyarakat puas terhadap puskesmas dan menjadikan puskesmas sebagai tempat rujukan pertama bagi masyarakat. Standar pelayanan tersebut meliputi prosedur pelayanan, waktu penyelesaian, biaya pelayanan, produk pelayanan, sarana dan prasarana, kompetensi petugas pemberi pelayanan serta kemudahan akses. Berdasarkan hasil wawancara, Puskesmas Simpang Baru melaksanakan pelayanan sesuai prosedur. Informasi mengenai prosedur pelayanan dapat diketahui oleh pasien dengan mudah dan jelas. Apabila ada hal yang tidak dimengerti oleh masyarakat dapat langsung menanyakan kepada petugas pendaftaran. Prosedur pelayanan juga tidak mengalami kendala dalam pelaksanaannya karena sudah sesuai dengan standar operasional. Hasil wawancara sesuai dengan Keputusan Menteri Pendayagunaan Aparatur Negara No. 63/KEP/M.PAN/7/2003, yaitu prosedur pelayanan publik sederhana, tidak berbelit-belit, mudah dipahami dan mudah dilaksanakan. Berdasarkan hasil observasi, kesederhanaan prosedur pelayanan telah terlaksana. Prosedur pelayanan tidak rumit dan pasien tidak mengalami kebingungan dalam mengikuti prosedur pelayanan. Petugas memberikan arahan kepada pasien yang belum mengerti prosedur pelayanan di Puskesmas Simpang Baru. Berdasarkan uraian tersebut, dapat diketahui bahwa Puskesmas Simpang Baru telah melakukan pelayanan sesuai dengan prosedur, dan informasi mengenai prosedur mudah dipahami oleh pasien.

\section{Waktu Penyelesaian Pelayanan di Puskesmas Simpang Baru}

Waktu merupakan elemen penting dalam pelaksanaan pelayanan. Ketepatan waktu penyelesaian pelayanan yang dijanjikan menjadi pegangan bagi pasien/masyarakat sebagai jaminan selesainya setiap pelayanan yang diberikan. Masyarakat sebagai pengguna pelayanan mengharapkan waktu penyelesaian benar-benar tepat sehingga tidak mengganggu aktivitas yang lain serta akan menghemat tenaga dan biaya. Berdasarkan hasil wawancara, waktu penyelesaian pelayanan tidak dapat dipastikan karena tergantung dari antrean dan keperluan setiap pasien. Pendaftaran pasien baru membutuhkan waktu sekitar 7 menit. Bagian pendaftaran memonitoring waktu yang dibutuhkan untuk setiap pasien baru dengan batasan waktu maksimal 10 menit sesuai dengan target yang telah ditetapkan di Puskesmas Simpang Baru. Jadwal pelayanan setiap harinya terletak di sebelah bagian kasir dan ruang KIA, sehingga pasien dapat mengetahui jadwal pelayanan yang berada di Puskesmas Simpang Baru. Berdasarkan hasil observasi, waktu penyelesaian yang dibutuhkan untuk setiap pasien tidak pasti karena tergantung dari banyak tidaknya pasien yang mengantri dan keperluannya. Rata rata waktu yang dibutuhkan untuk pendaftaran pasien baru selama 7 menit. Jadwal pelayanan berada di sebelah ruang kasir dan ruang KIA. Pelayanan dimulai pukul 07.30 sampai pukul 14.30 WIB untuk pelayanan hari Senin sampai Kamis. Pelayanan hari Jum'at dimulai pukul 07.30 sampai pukul 11.30 WIB. pelayanan hari sabtu dimulai pukul 07.30 sampai dengan pukul 13.00 WIB.

Berdasarkan uraian diatas dapat diketahui bahwa waktu penyelesaian pelayanan di Puskesmas Simpang Baru sesuai dengan Keputusan Menteri Pendayagunaan Aparatur Negara No.63/KEP/M.PAN/6/2003 salah satunya yaitu "Kepastian waktu artinya pelaksanaan pelayanan publik dapat diselesaikan dalam kurun waktu yang telah ditentukan". Hal lain seperti yang tercantum berdasarkan UU No. 25 Tahun 2009 tentang Pelayanan Publik yaitu ketepatan waktu dan kecepatan pelaksanaan pelayanan publik dapat diselesaikan dalam kurun waktu yang ditentukan dapat dipertanggungjawabkan sesuai dengan perundang-undangan dan masyarakat umum. 


\section{Biaya Pelayanan di Puskesmas Simpang Baru}

Biaya pelayanan merupakan biaya yang dikenakan untuk pelayanan yang telah diberikan. Pemerintah Kota Pekanbaru menetapkan tarif puskesmas yakni sesuai dengan Peraturan pelayanan kesehatan dasar dengan tarif gratis sesuai dengan Peraturan Daerah nomor 4 tahun 2012 tentang pelayanan kesehatan di Kota Pekanbaru.

\section{Sarana dan prasarana di Puskesmas Simpang Baru}

Penyediaan sarana dan prasarana pelayanan yang memadai oleh penyelenggara pelayanan mulai dari gedung, peralatan medis, perlengkapan kantor dan sarana dan prasarana penunjang pelayanan lainnya.Berdasarkan hasil wawancara, sarana dan prasarana di Puskesmas Simpang Baru masih ada kekurangan dibeberapa bagian. Gedung Puskemas Simpang Baru sudah cukup memadai, terdiri dari dua lantai. Peralatan medis maupun non medis yang dimiliki Puskesmas Simpang Baru masih belum terpenuhi seluruhnya, hal ini diakibatkan masalah birokrasi dengan pemerintah. Terdapat pula sarana dan prasarana lain yaitu ambulance, toilet, tempat bermain anak-anak, ruang tunggu, televisi. Puskesmas Simpang Baru juga menyediakan fasilitas lain seperti 80 kotak saran untuk menampung keluhan dari masyarakat yang dapat membantu Puskesmas memperbaiki pelayannya.

Berdasarkan hasil observasi, sarana dan prasarana yang ada di Puskesmas Simpang Baru terdiri dari ruangan di lantai bawah yang sebagian besar digunakan untuk kegiatan pelayanan tindakan medis seperti ruang tindakan, ruang BP Gigi, ruang BP Umum, ruang KIA/KB. Ruangan lantai atas sebagian besar digunakan untuk ruangan pelayanan non medis, seperti ruang Kepala Puskesmas, ruang Tata Usaha, Aula. Beberapa sarana yang masih belum terpenuhi diantaranya seperti yang berada di ruang Laboratorium belum ada pembatas ruangan, sirkulas udara hanya menggunakan kipas angin sehingga temperature ruangan kurang kondusif, dan peralatan laboratorium yang kurang lengkap.

Berdasarkan uraian tersebut dapat diketahui bahwa Puskesmas Simpang Baru masih perlu adanya peningkatan sarana dan prasarana yang memadai demi peningkatan pelayanan. Sesuai dengan salah satu prinsip pelayanan yang tercantum dalam Keputusan Menpan No. 63/KEP/M.PAN/7/2003 yaitu tersedianya sarana dan prasarana kerja dan pendukung lainnya yang memadai termasuk penyedia sarana teknologi telekomunikasi dan informatika. Dalam UU No. 25 Tahun 2009 dijelaskan bahwa penyediaan fasilitas dan sarana prasarana pelayanan yang memadai oleh penyelenggara pelayanan publik.

Uraian hasil dan pembahasan dari penelitian penulis. Bagian pembahasan memaparkan hasil penemuan secara logis, mengaitkan dengan sumber rujukan yang relevan. [font Times New Roman, 12, normal]. (dalam bentuk tabel dan gambar maupun grafik disesuaikan dengan format batas artikel). Pembahasan Penjelasan tentang hasil penelitian, dan itu sehubungan dengan hasil penelitian sebelumnya. Penjelasan tentang bagaimana temuan penelitian yang dilakukan dukungan atau konflik dengan penelitian yang ada.

\section{KESIMPULAN}

Berdasarkan hasil penelitian dan pembahasan tentang pelaksanaan pelayanan di Puskesmas Simpang Baru Kota Pekanbaru, maka dapat diambil kesimpulan sebagai berikut:

1. Prosedur pelayanan tidak berbelit-belit dan mudah dipahami oleh pasien. Prosedur pelayanan sudah cukup jelas, dapat dilihat pada bagian poli masing-masing.

2. Waktu penyelesaian pelayanan di Puskesmas Simpang Baru Kota Pekanbaru tidak dapat dipastikan karena lama atau tidaknya pelayanan tergantung dari jumlah pasien dan keperluannya. 
3. Biaya pelayanan di Puskesmas Simpang Baru Kota Pekanbaru sudah terperinci dengan jelas dan transparan. Biaya pelayanan di Puskesmas Simpang Baru mengacu pada Peraturan Daerah Nomor 4 Tahun 2012

4. Sarana dan prasarana Puskesmas Simpang Barukurang lengkap. Beberapa bagian poli masih kekurangan sarana maupun prasarana

\section{DAFTAR PUSTAKA}

[1]. Asrida, W., \& Pohan, R. P. Pelayanan Publik Pada Pusat Kesehatan Masyarakat Kecamatan Marpoyan Damai Pekanbaru Tahun 2013. Nakhoda: Jurnal Ilmu Pemerintahan, 13(21), 22-32

[2]. Bandiyono, A. Penerapan pelayanan publik di kantor pelayanan pajak. Jurnal Demokrasi Dan Otonomi Daerah, 16(1), 19-24.

[3]. Hamzah, O. S. (2016). Perilaku Birokrasi Pemerintah Dalam Pelayanan Puskesmas Di Kota Makassar. Jurnal Ilmiah Ilmu Administrasi Publik, 4(1), 30-45.

[4]. Ishak, D., Maolani, D. Y., \& Engkus, E. (2017). Konsep Kinerja Dalam Studi Organisasi Publik. JISPO: Jurnal Ilmu Sosial dan Ilmu Politik, 7(2), 101-120

[5] Maryam, N. S. (2016). Mewujudkan good governance melalui pelayanan publik. Jurnal Ilmu Politik dan Komunikasi: Politeknik Kridatama Bandung.

[6]. Tumiwa, R., Pangemanan, S., \& Sondakh, E. (2018). Efektivitas Kualitas Pelayanan Kesehatan Masyarakat pada Puskesmas di Kecamatan Dumoga. Jurnal eksekutif, 1(1).

[7]. Sari, A. Studi Tentang Pelayanan Publik Di Pusat Kesehatan Masyarakat Wonorejo Kecamatan Sungai Kunjang Kota Samarinda. 